\title{
Differences of Participation Rate of Livestock Group Member in Partnering and Non-Partnering with University in Tanete Riaja District Barru Regency
}

\author{
Mirnatul Qinayah¹, SittiNurani Sirajuddin², Aslina Asnawi², Ahmad Ramadhan Siregar², Mahyuddin ${ }^{3}$, \\ Rahmadanih $^{3}$
}

${ }^{1}$ Agribusiness Study Program Student, Post Graduated School of Hasanuddin University

${ }^{2}$ Lecturer of Soscio Economic Department Faculty of Animal Science, Hasanuddin University

${ }^{3}$ Lecturer of Agribusiness Program, Postgraduate School of Hasanuddin University

Correspondence Author: Mirnatul Qinayah, Agribusiness Study Program Student, Post Graduated School of Hasanuddin University Email: mirnatul.qinayah95@gmail.com

Received date: 28 August 2019, Accepted date: 2 December 2019, Online date: 31 December 2019

Copyright: (C) 2019 Mirnatul Qinayahet al.,This is an open-access article distributed under the terms of the Creative Commons Attribution License, which permits unrestricted use, distribution, and reproduction in any medium, provided the original author and source are credited.

\begin{abstract}
The aims of the research is to know differences participation rate of livestock group member in partnering and non-partnering withHasanuddin Univerity in Tanete Riaja Dsitrict Barru Regency in the development of beef cattle to improve the utilization of existing resources. The study was conducted at October-November 2019 in Tanete Riaja District, Barru Regency. The research location was determined purposively with the consideration that in the area it was the location of beef cattle breeding centers which were managed by Hasanuddin University together with the Regional Government of Barru Regency. Determination of the breeder as sample is purposive by the number of respondents as many as 33 partners farmer and proportional random sampling counted 38 non-partner farmers. This type of research is comparative research. The research data were collected by conducting a survey using a collection technique, namely interviews using a questionnaire. Data analysis is descriptive statistics using a frequency distribution table. The results of the research show that the participation of members of partner farmer / livestock groups is in the high category while non-partners are in medium category.
\end{abstract}

Keywords: participation, members of livestock group, profit-sharing partnership, university.

\section{INTRODUCTION}

Entering the era of the industrial revolution 4.0, agricultural development faces various challenges, namely the fulfillment of food sufficiency, improving the welfare of farmers, and providing employment. One of the leading agricultural sub-sectors in Indonesia as a supporter of economic growth is livestock. In order to support the acceleration of growth in the field of animal husbandry needed appropriate technology that can support the people's livestock business. The research results prove the application and development of technology plays an important role in increasing cattle production with traditional rearing. For maintaining the genetic quality of the cattle population and the development of coastal needed appropriate technology innovation, which are crucial to support the development of more advanced animal husbandry, modern, professional, and sustainable. The development of the cattle market business needs to be tackled in several ways, including sharing system partnership among breeders [1]

Utilization of breeding technologies to increase the productivity of cattle and creating the right economic independence of farmers. Lack of quality feed in the dry season, limited grazing land, high levels of morbidity and mortality in the rainy season, limited access to livestock health services and lack of knowledge of farmers in processing feed and livestock waste, is a problem faced by farmers. Animal waste in the form of livestock manure is only left piled outside the cage without further processing [2]. Hasanuddin University is a place for the development of science and technology. In running the Tridarma of Higher Education, namely community service at Hasanuddin University, has made a partnership program for the results of cooperation with farmers in several regions, one of which is in Barru Regency, South Sulawesi. Business cooperation with the partnership system is manifested in contracts that bind the parties to the agreement. The contract contains a number of clauses that must be obeyed by the parties but still must consider several applied ethics and regulations. The contract must consider the principle of equality and balance so that it must benefit the parties. The contract that was carried out also did not violate the principle of fair business competition and did not lead to monopolistic practices [3]. 
The profit-sharing partnership system of Hasanuddin University has several programs in empowering partner breeders and providing assistance in running their businesses. Providing instruction to farmers about technology in the field of animal husbandry as well as consultation to members of livestock groups about animal husbandry and handling of animal health. Hsanudin University also contributed to increasing their income [4]. With the production sharing partnership in Barru Regency it is hoped to increase the participation of farmer/livestock group members in developing their livestock business due to the assistance provided by Hasanuddin University and the local government of Barru Regency. Therefore, researchers are interested in conducting research by looking at differences in the participation of farmer/livestock group members who partner and do not partner with Hasanuddin University in conducting beef cattle maintenance cooperation.

\section{RESEARCH METHODS}

The study was conducted in October-November 2019 in Tanete Riaja District, Barru Regency.The population in this study was beef cattle breeders who collaborated with raising cattle with Hasanuddin University in Tanete Riaja District, BarruRegency with 63 farmers spread across 9 villages. The research sample is all or part of the population that is the object of research [5]. Determination of the breeder as sample bepurposive by the number of respondents as many as 33 people breeder partners and proportional random sampling counted 38 non-partner farmers. This type of research is comparative research. The research data were collected by conducting a survey using a collection technique, namely interviews using a questionnaire. The questionnaire used was a closed and open questionnaire. The form of questions in the questionnaire are closed questions and open questions. The variable in this study is the participation of farmer/livestock group members in the effort of beef cattle starting from the planning, implementation, utilization of the results to the evaluation stand. Measurement of research variables is done through measuring indicators for each variable/sub variable of the relevant research. For qualitative variable indicators measured using a Likert scale consisting of three levels, each given a score of 1, 2, and 3. Measurement of each variable research is also conducted through the withdrawal of the average value - an average of score of all indicators and sub-variables. Analysis of the data obtained from the survey begins with tabulating data and doing descriptive analysis of the data by looking at averages, percentages and frequencies.

\section{RESULT AND DISCUSSION}

The general state of the farmer respondents concerning gender, u bolts, education, number of livestock, cattle breeding experience pieces, shown in Table 1.

Table 1: The dominant characteristics of respondents

\begin{tabular}{|c|c|c|c|}
\hline General Characteristics of Respondents & Dominant Characteristics & Frequency & Percentage \\
\hline Gender & Male & 69 & $97 \%$ \\
\hline Age & $15-64$ years old & 71 & $100 \%$ \\
\hline Education & SMA / equivalent & 37 & $52 \%$ \\
\hline Livelihood & Farmers / Breeders & 60 & $85 \%$ \\
\hline Breed Experience & $6-10$ years & 31 & $44 \%$ \\
\hline
\end{tabular}

Source: Primary data after processing, 2019

\subsection{Gender}

Based on Table 1. Shows that the characteristics of respondents who partnered with Hasanuddin University, most of them are men were 69 people with a percentage of $97 \%$, while women only 2 people with a percentage of $3 \%$. This is due to the fact that this business requires more energy in its maintenance. However, it is possible for men and women to work together with each other. Proper handling and proper placement of work positions will also increase effectiveness and productivity as a trigger for the success of a business

[6].

\subsection{Age}

Based on Table 1. Shows that, range of the age according to the Central Statistics Agency, based on the composition of the population, devided into 3 groups such as: (1). 0-14 years old: young, (2). 15-64 years old: Adult / productive, (3). > 65 years old: Old / unproductive. All respondents belong to the category of adult age / working age / productive age. It's indicates that a person's age determines achievement and work performance. Physically, the older person will decrease its performance. However, when it comes to responsibilities the older age will have no effect, but rather the more experienced.

\subsection{Education}

Based on Table 1. The level of education completed by breeders who partnered with Hasanuddin University is the level of education of Graduated Student by 1 person (3\%), senior high school / equivalent by 37 people (52\%), junior high school / equivalent by 21 people (30\%), and Elementary School / Equivalent of 12 people ( 17\% ). The education level of high school / equivalent respondents is the dominant education level of the respondents. This shows that farmers also need education in running their livestock business. Education is also very important to support business progress. It is accordance with the opinion [7], which states that, the level of education affects the ability of farmers in the application of technology, besides that the level of education can be used as a benchmark against the ability to think someone in dealing with problems in the family can 
be immediately overcome. If education is low then the power of thought is narrow then the ability to reason a new innovation will be limited, so the insight to progress is lower than that of highly educated farmers. Farmers who have higher thinking power and are flexible in responding to a problem, they will always try to improve a better level of life [8].

\subsection{Profession}

Based on Table 1. shows that the profession of respondents in Tanete Riaja District, Barru Regency consisted of several occupational groups, namely farmers / ranchers, entrepreneurs, housewife, employees / teachers, members of Indonesian national army and the school guard. Most of the work done by respondent farmers was 60 farmers with a percentage (85), followed by entrepreneurs as many as 5 people (7\%), housewife as much as 2 people (3\%), employees / teachers, members of members of Indonesian national army $(2,5 \%)$ and school guard one person each (2,5\%). The profession that many people do is not only farmers but there are several other jobs. This shows that farmers who are members of livestock farmer groups are not only focused on agriculture but also are involved in work, especially in rural areas..

\subsection{Breed Experience}

Based on Table 1. The experience of raising livestock greatly affects farmers in running their livestock business which can be seen from the results of production. Farmers who have long been engaged in farming have a high level of knowledge, experience and skills in running a farm. The experience of farming is divided into four categories: less experienced (less than 5 years), quite experienced (5-10 years) and experienced (11-15 years) and very experienced (over 16 years). Farming experience will help farmers in making farm business decisions.

\subsection{The difference in Participation of Farmers / Livestock Group Members who Partner and Not Partnering with Hasanuddin University}

Participation is an activity in the form of awareness or voluntary and the ability to carry out development activities from planning to implementation based on the needs of the local community. Community participation initiatives must be developed to support needs, potentials and abilities [9]. The level of community participation is the involvement of the community in joint actions aimed at welfare in situations and conditions that are created together as the same rights and obligations in the planning stage, the implementation stage, the evaluation stage and the enjoyment stage of the results [10]. Based on the results of research conducted in Tanete Riaja District, Barru Regency, it can be seen the differences in the participation of members of livestock groups who are not partnering and those who partner with Hasanuddin University can be seen in Table 2.

Based on the data in Table 2, it can be seen that there are differences in the average level of participation of nonpartnering farmer / livestock groups and those who partner with Hasanuddin University. There is a difference level of participation, non-partner farmers an average score of her that is 82 with the category "medium" and breeders' partners average score of 85 categories of "High". It is happen because since there is a partnership of revenue sharing between the University of Hasanuddin with farmers in Barru Regency, farmers have become enthusiastic to participate in this program. In addition, activities carried out such as assistance and training to farmers involving professors from the Faculty of Animal Scinece of Hasanuddin University.

Table 2: The results of the analysis of the participation rates of members of farmer/livestock groups

\begin{tabular}{|c|c|c|c|c|c|c|c|c|c|c|}
\hline \multirow{3}{*}{ Level of Participation } & \multicolumn{5}{|c|}{ Partner Farmers } & \multicolumn{5}{|c|}{ Non-Partner Farmers } \\
\hline & \multicolumn{3}{|c|}{ Benefit Score } & \multirow{2}{*}{$\begin{array}{c}\text { Participation } \\
\text { Score }\end{array}$} & \multirow{2}{*}{\begin{tabular}{|c|} 
Participation \\
Category
\end{tabular}} & \multicolumn{3}{|c|}{ Benefit Score } & \multirow{2}{*}{$\begin{array}{c}\text { Participation } \\
\text { Score }\end{array}$} & \multirow{2}{*}{$\begin{array}{c}\text { Participation } \\
\text { Category }\end{array}$} \\
\hline & 3 & 2 & 1 & & & 3 & 2 & 1 & & \\
\hline \multicolumn{11}{|c|}{ 1. Planning Phase } \\
\hline Present at the meeting & 24 & 9 & 0 & 90 & High & 11 & 24 & 3 & 84 & Medium \\
\hline Put forward ideas & 9 & 22 & 2 & 73 & Medium & 9 & 27 & 2 & 83 & Medium \\
\hline Give a rebuttal & 11 & 20 & 2 & 75 & Medium & 8 & 25 & 4 & 78 & Medium \\
\hline \multicolumn{4}{|c|}{$\begin{array}{c}\text { Average } \\
\end{array}$} & 79 & High & & & & 82 & Medium \\
\hline \multicolumn{11}{|c|}{ 2. Implementation Stage } \\
\hline $\begin{array}{l}\text { Present in } \\
\text { keg. counseling / } \\
\text { training }\end{array}$ & 26 & 7 & 0 & 92 & High & 10 & 27 & 1 & 85 & Medium \\
\hline $\begin{array}{c}\text { Contribution of } \\
\text { material, energy, etc. }\end{array}$ & 18 & 15 & 0 & 84 & High & 8 & 26 & 4 & 80 & Medium \\
\hline \multicolumn{4}{|l|}{ Average } & 88 & High & & & & 83 & Medium \\
\hline 3. Utilization of results & 20 & 13 & 0 & 86 & High & 11 & 27 & $\mathbf{0}$ & 87 & Medium \\
\hline \multicolumn{11}{|c|}{ 4. Evaluation Phase } \\
\hline Present at the meeting & 20 & 13 & 0 & 86 & High & 12 & 22 & 4 & 84 & Medium \\
\hline $\begin{array}{l}\text { Raise criticism and } \\
\text { suggestions }\end{array}$ & 21 & 12 & 0 & 87 & High & 5 & 28 & 5 & 76 & Medium \\
\hline \multicolumn{4}{|l|}{ Average } & 87 & High & & & & 80 & Medium \\
\hline Average & & & & 85 & High & & & & 82 & Medium \\
\hline
\end{tabular}

Source: Primary data after processing, 2019. 


\section{Planning Stage}

The planning stage is the initial stage in formulating the problem, determining the program to be made, the targets and targets to be achieved from the activities to be carried out. At this decision making or planning stage, the level of participation of partner farmers is in the high category compared to non-partner farmers in the medium category. Indicators used in the planning stage are attendance at meetings, the submission of ideas/opinions, and rebuttal to the decision of the meeting to be carried out in the implementation of beef cattle business activities so that it can be achieved optimally. In attendance indicators in attending meetings, the average partner farmers are in the high category which means that farmers are often present every time there is a meeting, this is because there is information from the group leader to members about the meeting time and meeting time does not coincide with working time in the fields with other work. While for non- partner farmers, the average participation is in the medium category which means that partner farmers sometimes attend meetings.

Indicators of submitting ideas/opinions and rebuttal to the decision of the meeting, the average participation of farmers and nonpartner breeders are equally in the medium category, this shows that the breeders of partners and non-partners are less in giving opinions. This is due to the dominance of the delivery of ideas/ideas by the group leader, so that member breeders only slightly add suggestions for the smoothness of the activities to be carried out. Most of the people with low education are also the reason for the lack of farmers' participation in delivering ideas. Education owned by community members will influence the way of thinking. Community members with relatively high education will be more dynamic and have a broader mindset when compared to members of the community with less education.

\section{Implementation Stage}

The implementation phase in this study is an activity that is realized by the involvement of farmers in the implementation of livestock business implementation. Indicators of the implementation stage are the participation of farmers in training/counseling on the development of livestock businesses and the contribution of farmers in the form of material or personnel. At the implementation stage, participation shows that partner farmers are in the high category while partner farmers are in the medium category. Indicator of participation in training or counseling, partner breeders on average are in the high category which means farmers often attend counseling/training this is because if there are activities such as training/counseling held by the Unhas, farmers are given transportation costs to be able to attend these activities so that farmers become enthusiastic about participating in the activity because of the rewards they get, this is supported by opinions [11] which concluded that there are several factors that can influence participation such as farmers' experience/insight, age, motivation, education, communication, group dynamics, cohesiveness, attitude or perception, and the role of a companion. Added the results of research conducted by the Team from Padjadjaran University [12] showing that the main motivation for the participation of farmer group members is more inclined to be driven by a desire to improve the ability to farm and fulfill basic needs. While the average non-partner breeders are in the medium category which means that non-partner breeders sometimes attend counseling/training. This happens because of the lack of motivation of non-partner farmers to end counseling/training. Access cooperative farmers and extension agents can increase the productivity of farmers [13].

Based on the indicators giving contributions in the form of material or energy, the average partner farmers are in the high category while the non-partner farmers are in the medium category. Contributions given by breeder partners in the form of energy. This is in line with what was stated by [14] that community participation in farmer groups is basically a variety of forms such as participation in the form of ideas, energy, skills, objects and funds (money). While the average non-partner breeders are in the medium category, which means that non-partner breeders sometimes / less contribute to the implementation of group activities. This relates to the activities organized by the group that is lacking so that they do not really need donations in the form of funds or personnel.

\section{Enjoying the Results Stage}

At the stage of enjoying the results is the involvement of farmers in obtaining the benefits of activities. The high participation of the members of the partner breeders group at the stage of enjoying the results because at this stage the farmers know the profitsharing from the sale of their cattle honestly, fairly and transparently. Farmers enjoy individually with profits from the sale of livestock, which is obtained individually and there is a guarantee of marketing of livestock that will be sold. While the average participation of farmers in enjoying the results, non-partner farmers are in the medium category, this is because farmers sell and utilize individually the results of their livestock, but in the case of marketing, non-partner farmers have no marketing collateral.

\section{Evaluation Stage}

This stage is the evaluation/evaluation stage in determining the improvement of activities that have been carried out. This stage looks at problems or obstacles and the success of the activities carried out so that improvements can be made. At the evaluation stage participation refers to Table 2. shows that the average partner farmers are in the high category while the average nonpartner farmers are in the medium category. Indicators of participation at the evaluation stage are attendance at evaluation meetings and providing criticism and suggestions. Based on the attendance indicators in the evaluation meeting, partner farmers are in the high category while non-partner farmers are in the moderate category. This shows that partner farmers are often present in evaluation meetings, farmers believe that the importance of the evaluation phase in the improvement and development of livestock business further, while for partner farmers show that the lack of participation of non-partner farmers, this indicates that at the evaluation stage not yet done optimally. At this evaluation stage, the average participants included are those who have direct interests in the program such as the group leader and core cadres only, and after that, the results are given the results to the group members. The implication was local government especially should give more extension to farmers. [15] 


\section{CONCLUSION}

Based on the results and discussion, it is concluded that the participation of members of partner farmer/livestock groups is in the high category while non-partners are in medium category.

\section{REFERENCES}

[1] Sirajuddin, S.N, A.R. Siregar, S. Nurlaelah, V. Tenrisanna. 2017. The Limitations and Benefits of Partnership Sharing System of Corporated Cattle Market (CCM). American-Eurasian journal of sustainable Agriculture. 11 (1):(11-14)

[2] Laut, Meity, Winarso, A., Anggadewi, N., Benu, I. 2018. Penerapan teknologi peternakan sebagai upaya peningkatan produksi ternak sapi potong di desa Penfui Timur, kecamatan Kupang Tengah, kabupaten Kupang. Jurnal Pengabdian Masyarakat Peternakan. 3(1) ISSN: 2502-5392.

[3] Sirajuddin, S. N., Nurlaelah, S., Amrawaty, A., Amrullah, T., Rohani, S. and Saleh, I. M. 2017. Relationship Between Farmers Characteristic and Income from Beef Cattle with The Traditional Profit-Sharing. American-eurasian journal of sustainable Agriculture .11(5):29-34.

[4] Sirajuddin, S.N., Hastang, V.N. Lestari, Rosmawaty. 2019. Livestock ecology research on institution and traditional sharing systems in cattle farms. Eurasia J Biosci. $13: 239-244$

[5] Arikunto. 2006. Prosedur Penelitian Suatu Pendekatan Praktek. PT. Rineka Cipta. Jakarta

[6] Adi, I. Rukminto. 2007. Intervensi Komunitas Pengembangan Masyarakat sebagai Upaya Pembedayaan Masyarakat. PT. Rajagrafindo Persada. Jakarta.

[7] Lestraningsih, M., dan Basuki, E. 2008. Peran Serta Wanita Peternak Sapi Perah dalam Meningkatkan Taraf Hidup Keluarga. Jurnal Ekuitas. Sekolah Tinggi Ilmu Ekonomi Indonesia (STIESIA). Surabaya.

[8] Irene Kartika Eka Wijayanti, Jamhari, Dwidjono Hadi Darwanto, Any Suryantini. 2019. Production Risk and Factors Influencing Strawberry Farming in Purbalingga Regency, Indonesia. American-Eurasian Journal Of Sustainable Agriculture. 13 (1): 9-17.

[9] Hadi S. 2014. Profil Modal Sosial dan Tingkat Partisipasi Peternak pada Pengembangan Sapi Potong di Kabupaten Tebo Provinsi Jambi. Jurnal Kanal. 8(4):341-348.

[10] Cohen JM dan Uphoff NT. 1979. Feasibility and Application of Rural Development Participation: A State of The Art Paper. [diunduh 16Januari 2017]. Tersedia pada http://pdf.usaid.gov/pdf_docs/ PNAAL936.pdf.

[11] Husodo, S. 2006. Partisipasi Petani dalam Kegiatan DAFEP di Kabupaten Bantul. Jurnal Ilmu-Ilmu Pertanian. 2 (2).

[12] Mardikanto, T. 2007, Sistem Penyuluhan Pertanian. Sebelas Maret University Press. Surakarta.

[13] Amrawaty, A. A, Ikrar M. Saleh, Jamila. Relationship of Farmer's Characteristics with Adapted Choice in Facing of the Lack Feeding in Barru Regency. AENSI Journals Advances in Environmental Biology ISSN-1995-0756 EISSN-19981066. Advances in Environmental Biology, 11(12): 21-25.

[14] Hamidjoyo, S, 1991. Women's Involvement in the Conservation Farming System of Selami Das Brantas in Malaya Regency. Village Development Foundation, Malang.

[15] Veronica Sri Lestari, Sitti Nurani Sirajuddin, Kasmiyati Kasyim. Perception of Beef Cattle Farmers toward Biosecurity Practices. AENSI Journals . Advances in Environmental Biology. 9 (24): 450-452. 